\title{
David Hume \\ Filósofo e Historiador
}

\section{Sara Albieri ${ }^{1}$}

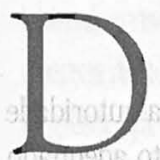

entre todos os grandes filósofos, David Hume tem o raro mérito de acrescentar, à obra propriamente filosófica, um trabalho de historiador igualmente importante. Publicou uma História da Inglaterra em vários volumes, abrangendo desde a invasão de Júlio César até a Revolução de 1688, que teve repercussão imediata e duradoura. A primeira edição conjunta da História, em oito volumes, foi publicada em 1763 , mas não foi escrita nessa ordem. 0 sexto volume e parte do sétimo, contendo os reinados de Jaime I e Carlos I surgiram em primeiro lugar, num único volume publicado em 1754. Um segundo volume (final do sétimo e oitavo na versão conjunta) datado de 1757, continuava a História até a Revolução de 1688. Em 1759, foram publicados dois volumes sobre a Casa Tudore, finalmente, datados de 1762 , outros dois volumes abrangiam o período que se estendia desde a invasão de Júlio César até a subida ao trono de Henrique VII, num total de seis volumes, depois desdobrados em oito, em ordem cronológica, para a primeira edição conjunta. Em seguida a esta, foram publicadas sucessivamente várias outras edições completas, sempre revistas pelo autor, até a de 1778 , publicada dois anos após sua morte.

A inversão cronológica adotada por Hume ao escrever sua História foi em grandeparte responsável pela repercussão junto à opinião pública logo quando de sua primeira publicação. A questão da tirania dos Stuarts e da legitimidade da execução de Carlos I ainda provocava controvérsia entre seus contemporâneos, imiscuída sempre nos debates políticos. E Hume, confessando-se "amedrontado com a idéia de continuar uma narrativa por um período de 1700 anos", iniciara sua História justamente pela ascensão da Casa Stuart, quando julgara terem começado a ocorrer as principais "desfigurações partidárias". ${ }^{2}$ A essa altura Hume já era um autor conhecido, e sua obra, lançada na atualidade de tal polêmica, foi acolhida com um interesse que não acompanhara a publicação de seus primeiros escritos filosóficos. Mas a súbita

\footnotetext{
1 Professora do Departamento de História da UsP.

2 Hume. My own life. In: ——The History of England. Londres: T. Cadell, 1978. p.XI.
} 
popularidade não significou unanimidade. AHistória humeana contrariava em muitos pontos uma certa interpretação liberal dos eventos passados, bastante favorecida pela opinião pública, por isso foi recebida como um ataque de fundo conservador a que era preciso revidar. Instalouse em breve a celeuma, salutar para a divulgação da obra, mas surpreendente e mesmo decepcionanteparaseu autor.

Hume julgara ter escrito uma narrativa histórica imparcial, que pudesse sustentarse acima do conflito das interpretações partidárias, esperando persuadir as partes em disputa e atrair o consenso das opiniões. A celeuma provocada contrariou-lhe vivamente as expectativas, conforme nos testemunha na autobiografia:

Pensei ser 0 único historiador a ter ignorado tanto o poder, o interesse e a autoridade presentes, como o clamor dos preconceitos populares; e sendo 0 assunto adequado a todas as capacidades, aguardei um aplauso proporcional. Mas foi grande minha decepção: fui agredido por um clamor de crítica, desaprovação e até ódio; ingleses, escoceses e irlandeses, whigs e tories, clérigos e sectários, livres-pensadores e religiosos, patriotas e partidários da corte, uniram-se na ira contra o homem que ousara derramar uma lágrima generosa pelo destino de Carlos I e do Conde de Stratford. ${ }^{3}$

Hume pôde constatar que "o partido whig estava no controle de tudo, no Estado e nas Letras", mas mesmo assim resolveu não ceder a seu "clamor insensato". Assim, as "mais de cem alterações" a que procedeu nos reinados dos dois primeiros Stuarts, motivadas pelo "estudo, leitura ou reflexão", fê-las todas "invariavelmente para o lado tory". " $\mathrm{Na}$ verdade, a pretensão de que opiniões moderadas pudessem agradar a todas as facções só poderia ser mal acolhida pela sociedade inglesa da época, na qual o ponto de vista corrente era o de que a melhor história da Inglaterra seria aquela escrita por um estrangeiro. Só alguém imune às paixões envolvidas nos debates partidários poderia interpretar a história inglesa de maneira verdadeiramente imparcial. A essa crença generalizada deveuse o prestígio alcançado pela história da Inglaterra publicada pelo francês Rapin-Thoyras (entre 1726 e 1731). 0 próprio Rapin chamou a atenção para a interferência dos partidos whig e tory na elaboração de uma história imparcial; ele confessava "poucas esperanças de ver uma história imparcial da Inglaterra a partir do começo do reinado do rei Jaime I até a nossa época. Para qualquer lado que um historiador se volte, será tomado como

3 Id. Ib., p. xi.

4 Id. Ib., p. xii.

5 Rapin-ThoYras. The History of England, v. IX, p. 337. Apud. ForBes, D. Hume's Pbilosopbical Politics. Cambridge: Cambridge University Press, 1975. p. 234. 
parcial por uma ou outra das duas facções". ${ }^{5}$ Mas sua leitura da origem e do desenvolvimento histórico da constituição inglesa servia aos pontos de vistas liberais; quanto aos conservadores, objetavam que, justamente por ser estrangeiro, não poderia haver bem compreendido o funcionamento da constituição inglesa. ${ }^{6}$ Foi por divergirem neste ponto crucial que as pretensões de Hume ao consenso tiveram pior sorte.

0 ideal da imparcialidade já orientava Hume antes da publicação da História, como parte integrante de sua teoria política. No ensaio "Da Sucessão Protestante", ao analisar as vantagens e desvantagens da ascensão da Casa de Hanover ao trono da Inglaterra, Hume defende o caráter não-tendencioso, moderado, de suas reflexões: "compete apenas ao filósofo, que não pertence a nenhum desses partidos, pesar todas as circunstâncias e atribuir a cada uma delas seu verdadeiro valor e influência". Manter-se equidistante das partes em disputa, eis a atitude que valoriza o discurso filosófico sobre a opinião. 0 filósofo reconhece "que todas as questões políticas são infinitamente complicadas", e por isso não se deixa tomar pelas paixões ao considerar o que está em jogo, mas antes hesita, duvida, distinguindo-se pela reserva e moderação da "multidão ignorante, que ésempre vociferante e dogmática, mesmo em relação às questões mais sutis, das quais, talvez mais ainda por falta de moderação que de entendimento, são totalmente incapazes de ser juizes". ${ }^{7}$ Portanto, Hume não busca a imparcialidade apenas como um meio de obter aceitação e prestígio junto à opinião pública, mas antes de tudo como uma qualidade essencial à constituição do discurso filosófico. A imparcialidade é quase que uma linha de demarcação que separa as ponderações do filósofo da expressão apaixonada da opinião. Ao escrever a História da Inglaterra, Hume procura manter essa mesma postura, de resto não inédita na historiografia do século XVIII.

A história filosófica do século XVII inaugura uma nova forma de pensar a história. Segundo seus escritores, a historiografia anterior relatava os eventos de maneira fragmentada: ocupava-se de guerras, de tratados, de tiranos ou de sucessões monárquicas, de viagens e conquistas, porém enquanto temas isolados. 0 historiador pouco se interessava por abranger a totalidade dos costumes de um povo, suas instituições políticas, financeiras, sociais. A maneira de escrever a história atinha-se à narração, ao relato: 0 historiador equiparava-se ao cronista. Tratava-se de registrar, de enaltecer, de vilipendiar, de lamentar, mas não de explicar. Fénelon expressa sua insatisfação com o "árido e triste escritor de

6 A esse respeito ver em ForBEs, D. Id. Ib., cap. III, um minucioso exame das publicações da época, sobretudo dos debates surgidos em periódicos.

7 Ensaios morais, políticos e literários. In: Hume/Berkeley. Col. Os Pensadores. São Paulo: Abril Cultural, 1980. p. 247. (Tradução utilizada nas citações). 
anais", que "não conhece outra ordem senão a da cronologia", enquanto que mais importante seria "observar as mudanças da nação como um todo do que relatar fatos particulares". Também Fontenelle critica a tradição que confunde o saber histórico com "comprimir na cabeça fato após fato, reter datas com exatidão, imbuir-se do espírito das guerras, tratados de paz, matrimônios, genealogias" ${ }^{8}$ E Voltaire, ele próprio autor de uma obra de história, o Ensaio sobre os Costumes e o Espirito das Nações, comenta que a leitura de "três ou quatro mil descrições de batalhas" em nada contribui para a instrução de alguém, uma vez que tais relatos tratam apenas de "eventos", pelos quais negligenciam-se "conhecimentos de uma utilidade mais sensível e durável" . 9 Contudo, quem quiser ler a história "como cidadão e como filósofo" procurará interessar-se pelas "mudanças nos costumes e nas leis"; só assim tomará conhecimento da "história dos homens, em lugar de saber uma pequena parte da história dos reis e das cortes". ${ }^{10}$ E a História da Inglaterra de Hume é saudada por Voltaire como exemplar desse novo procedimento: "Jamais o público percebeu tanto que só cabe aos filósofos escrever a história"."

Percorrendo o texto da História da Inglaterra, constataremos que, ao final de cada reinado importante ou de cada período, Hume sistematicamente tece considerações gerais sobre as formas de governo, finanças, organização militar, costumes, enfim tudo o que pudesse servir a um conhecimento mais amplo da sociedade e da natureza humana. Por exemplo, o início do Apêndice sobre o Reinado de Jaime I:

Poderá ser oportuno, neste ponto, fazer uma pausa: e afastando-nos um pouco do estilo histórico, proceder a uma observação do estado do reino com respeito a governo, costumes, finanças, armas, negócios, educação. Onde não se formar uma noção adequada desses particulares, a História será bem pouco instrutiva, e freqüentemente ininteligível. ${ }^{12}$

8 Fénelon, Oeuvres (1848-51), VI, p. 639-40. Fontenelle, Oeuvres (1790), V; p. 433. Becker, C. L. The Heavenly City of the Eigbteenth - Century Philosophers. New Haven: Yale University Press,1964. p. 91.

9 Cf. VourarRe. "Essai sur les Moeurs". In:_—. Oeuvres Complètes. Paris: Armand Aubrée, 1830.

10 VolTaire. Fragments sur l'Histoire, Art. XII. "Mélanges Historiques". In: — . Oeuvres Complètes. Vols. 2122. Paris: Armand-Aubrée, 1830. pp. 47-9.

$"$ VotTaIRE. "Réflexions sur l'histoire, et en particulier sur l'histoired'Angleterre, de M. Hume". Des Mensonges Imprimés. In: —. Mélanges Historiques, II, p. 416-20. Segundo C. BEcKER, todos os historiadores-filósofos dessa época "têm a mesma queixa, que os historiadores 'ortodoxos' acumulam fatos por amor aos fatos, todos fazem a mesma reivindicação, que a nova história deve ser escrita por filósofos, a fim de obter dos fatos aquelas verdades úteis que nos conduzirão a um conhecimento de nós mesmos e dos outros". Cf. BECKER. 1964, Op. cit., p. 91.

${ }^{12}$ Hume. The History of England. Vols. I a VIII, Caps. I a LXXI. Londres: T. Cadell, 1778. Indianapolis: Liberty Classics, 1983. vi, p. 157. 
A história filosófica tem, pois, novos objetos, e novos métodos de abordá-los. E essa preocupação metodológicaestáligada a um ideal de cientificidade. No século XVIII, a história, como a filosofia, tem inspiração newtoniana. ${ }^{13}$ Diz Voltaire nos Fragmentos sobre a História: "Ocorrerá talvez brevemente no modo de escrever a história o que aconteceu à física. As novas descobertas fizeram proscrever os antigos sistemas. Queríamos conhecer o gênero humano no detalhe interessante que é hoje a base da filosofia natural" ${ }^{14}$ Quanto a Hume, expressava claramente sua intenção de obter, para a ciência do homem de modo geral, o mesmo estatuto de cientificidade que Newton havia conquistado para a física:

Por muito tempo os astrônomos se haviam contentado em provar, com base nos fenômenos, os verdadeiros movimentos, ordem e grandeza dos corpos celestes; até que por fim surgiu um filósofo que parece, elo mais feliz dos raciocínios, ter também determinado as leis e as forças que governam e dirigem as revoluções dos planetas. Um trabalho semelhante foi realizado no que diz respeito a outras partes da natureza. E não há motivo para desesperarmos de um sucesso igual em nossas pesquisas sobre as faculdades e a economia mental, se as realizarmos com a mesma proficiência e a mesma cautela. ${ }^{15}$

A historiografia crítica produzida dentro desse paradigma orientava-se para a construção de uma ciência do homem, mas também enquanto fonte de dados sobre a conduta humana através dos tempos, enquanto base empírica. Inversamente, notadamente em Hume, os princípios gerais da natureza humana eram empregados na explicação dos fatos históricos, conferindo-thes assim um grau maior de inteligibilidade.

Para adequar-se ao novo método, a história filosófica desenvolve também um novo estilo de narrativa: claro e conciso, procurando adequar a economia da linguagem à ambição de precisão e certeza. Tal estilo contrasta nitidamente com o tipo de narrativa histórica desenvolvido no século XIX, com o qual estamos familiarizados. 0 estilo romântico ofuscou em grande parte a herança iluminista na historiografia, recusando aquilo que se lhe afigurava como fixidez a-histórica. ${ }^{16}$ Naturalmente, a narração histórica

13 "A filosofia do século XVIII desde o começo trata os problemas da natureza e da história como uma unidade indivisível. Tenta abordar os dois tipos de problema com os mesmos instrumentos intelectuais; fazer as mesmas perguntas e aplicar o mesmo método universal da razão à natureza e à história". CASSIRER, E. The Pbilosophy of the Enligbtenment. Boston: Beacon Press, 1966. p. 199.

14 VolTaIRE. 1830, Fragments sur l'bistoire, Op. cit., Art. XII, p. 46.

${ }^{15}$ HuMe. An Enquiry concerning Human Understanding. Partes I a III. Seções 1 a 12, $\S \S 1$ a 132. Selby-Bigge, ed. Oxford: Clarendon Press, 1957. I, §9.

16 "Uma noção favorita dos historiadores do século XIX era que o séculoXVIII era 'anti-histórico', que não estava interessado na História, uma vez que desejava 'romper com o passado' e começar de novo". Becker, C. 1964, Op. cit., p. 92. 
do século XVIII nada tem de poética; também não menciona a Divina Providência, e não se ocupa da cor local ou do sentimento nacional. Seu estilo não procura envolver o leitor em meio aos acontecimentos, ou fazê-lo identificar-se com os pensamentos e sentimentos dos principais atores do drama histórico: não há "grandes homens", no sentido de uma preocupação com a pintura dos personagens, para torná-los vívidos, atraentes ou inesquecíveis. Na verdade, o estilo "frio" da narrativa histórica iluminista não devia agradar aos românticos, tanto que, na Inglaterra do século XIX, a História da Inglaterra de Hume foi sendo gradualmente substituída como obra de referência por outra, escrita por Catherine Macaulay, porque esta atendia mais adequadamente ao anseio por uma narrativa vívida e apaixonada que pudesse contagiar o leitor. ${ }^{17}$

Talvez um estilo que mais se aproximasse das técnicas literárias parecesse menos adequado a um ideal de imparcialidade; de qualquer forma a história do século XVIII não recorria às figuras de estilo para cativar o leitor, com exceção, talvez, da ironia, empregada magistralmente por Voltaire, mas com não menor sutileza por Hume, como arma para denunciar o preconceito e o absurdo de certos relatos. ${ }^{18}$

A questão do estilo aparecia também ligada a um outro aspecto da narrativa histórica no século XVIII: o seu valor pedagógico. Rapin-Thoyras assegura que "o romance apenas agrada, a história instrui; esta éa diferença essencial entre eles, esta (aúltima) não tendo outra finalidade senão instruir opúblico". 0 historiador deveria "apenas pensar em ser útil, dirigindo os corações e as mentes dos homens pela instrução que lhes dá" . ${ }^{19} \mathrm{E}$ o historiador Bolingbroke segue-lhe os passos. Citando Dioniso de Halicarnasso, dizque "A históriaéafilosofiaensinando por exemplos". A virtude ensinada por preceitos gerais tem pouco efeito sobre nossas mentes: estes "parecem-nos com frequiência obscuros ou duvidosos, até que são explicados com exemplos" ${ }^{20} \mathrm{E}$ a históriaé veículo de instrução e de virtude.

17 Ver Forbes, D. Introduction. In: Hume, D. The History of Great Britain. Middlesex: Penguin Books, 1970. p. 17s; também em 1975, Op. cit., p. 284. Norton e Popkin consideram-na "uma resposta whig à História de Hume", e citam uma carta de Hume a Catherine Macaulay de 29 de março de 1764, em que este comenta divergências entre ambos. NoRTon, D. F. "History and Philosophy in Hume's Thought". In: NorTON, D. F \& PopkIN, R. S. (Orgs.) David Hume: Pbilosophical Historian. Nova York, Bobbs Merril, 1965. p. 407.

${ }^{18}$ A tese de JoHN W. PrICE em seu livro The Ironic Hume é de que a ironia faz parte integrante do ceticismo nos escritos filosóficos de Hume: "o ceticismo, não aceitando a autoridade do dogma ou o privilégio da tradição, pode tratar com ironia conceitos reverenciados, ao mesmo tempo apontando as falácias na lógica ou razão de uma dada posição". (p. 7). 0 Capítulo 3 trata especificamente do emprego da ironia no texto da História da Inglaterra, sobretudo quando se trata de política e religião. Cf. PRICE, J. V. The Ironic Hume. Austin: University of Texas Press, s./d.

19- RAPIN-THoyrAs. The Modest Critick: or Remarks upon the most eminent Historians, ancient and modern, p. 29s. Citado por Kramnick, I. Introduction. In: BolingBRoKe, LoRd. Historical Writings. Chicago: The University of Chicago Press, 1972. p. xviii.

20 BoLINGBROKE, LoRD. Letters on the Study and Use of History. In: —. Id. ib. p. 9. 
No ensaio "Do Estudo da História", publicado e posteriormente retirado de sua coletânea de ensaios, Hume, embora não desenvolvendo uma esperada teoria da história, elenca como principais vantagens relacionadas com o estudo da história agradar à imaginação, fortalecer a virtude e aprimorar o entendimento.

Como entretenimento, a história nos transporta ao passado para observar a infânciada sociedade humana, ver o refinamento progressivo das instituições políticas, notar a ascensão e quedados impérios: "emsuma, para ver toda a raça humana desde o começo dos tempos, passar em revista, tal como era, ante nossos olhos [...] Que outro espetáculo pode ser imaginado tão magnífico, tão variado, tão interessante?". ${ }^{21}$ Portanto, mesmo enquanto diversão para a imaginação, a história já é fundada na observação da vida humana, numa perspectiva privilegiada, que o tempo e a distância contribuem para criar, permitindo a observação de nosso objeto em "suas verdadeiras cores". Como se a leitura da história pudesse constituir-se como fonte de observação mais segura para o conhecimento da natureza humana do que nossas impressões presentes, originadas na experiência de nosso próprio tempo.

A influência da distância espaço-temporal sobre a imaginação humana já havia sido destacada por Hume em outra parte. No Tratado, Hume aponta para a característica da imaginação humana que tende a valorizar os objetos "mais pela luz sob a qual aparecem aos homens do que por seu valor real e intrínseco". 22 que nos é contíguo afeta-nos com uma idéia forte e viva, tem um efeito proporcional sobre a vontade e as paixões, e opera com mais força do que um objeto que se acha mais remoto, sob uma luz mais obscura. Da mesma forma, embora Hume não seja explícito neste caso, podemos inferir que os fatos históricos, embora se apresentem de maneira mais obscura à imaginação do que as impressões de fatos presentes, justamente pelo seu caráter remoto permitem que a sua observação seja mais isenta de paixão do que a observação de um fato atual, que pela contigüidade exerceria maior atração sobre as paixões, perturbando a exatidão de nossos julgamentos.

É justamente este aspecto que introduz o aprimoramento do entendimento, outra vantagem daquele que estuda história. Na verdade, se tivéssemos que limitar a base experimental da ciência do homem à "cuidadosa observação da vida humana" tal como "no curso comum do mundo" ao alcance de nossa observação pessoal, o escopo de nossos conhecimentos assim obtidos seria bastante limitado. É preciso acrescentar a esse acervo o testemunho de eventos passados, através do estudo da história:

${ }^{21}$ Hume. Essays Moral, Political and Literary. Indianapolis: Liberty Fund, 1985. p. 566.

${ }^{22}$ Hume. A Treatise of Human Nature. Selby-Bigge, ed. Livros I a III. Partes I a IV. Seções 1 a 16, páginas da edição. Oxford: Clarendon Press, 1967. 
Devo acrescentar que a história não somente é uma parte valiosa do conhecimento, mas abre as portas a muitas outras partes, e fornece material para a maioria das ciências. E na verdade, se considerarmos a brevidade da vida humana, e nosso conhecimento limitado, mesmo do que se passa em nosso próprio tempo, devemos reconhecer que seríamos para sempre crianças em nosso entendimento, se não fosse por essa invenção, que estende nossa experiência a todas as idades passadas, e às nações mais distantes, fazendo-as contribuir para 0 aperfeiçoamento de nosso conhecimento tanto quanto se estivessem de fato colocadas sob nossa observação. ${ }^{23}$

Já que todo conhecimento deve fundar-se na experiência, a história constitui para a ciência do homem, ao lado da vida quotidiana, a grande fonte de "observação" da natureza humana. A história desempenha, portanto, um papel fundamental na filosofia de Hume, na medida em que representa a condição de possibilidade do emprego do método experimental aplicado ao conhecimento da natureza física, também no-campo da filosofia moral.

0 estudo da história enquanto fortalecimento da virtude decorre das mesmas condições. Porque o historiador, estando mais próximo que qualquer outro de uma visãa da natureza humana isenta de paixão, tende a manter uma independência de julgamento que permite reconhecer o vício e a virtude, reprovando o primeiro e favorecendo a segunda. Assim, ao mesmo tempo em que se entretém com o espetáculo que o passado lhe oferece, mantém um distanciamento suficiente para colocá-lo em seu verdadeiro lugar: "Os escritores de história, tanto quanto os leitores, estão suficientemente interessados nos personagens e eventos para ter um sentimento vivaz de reprovação ou de apreço; e, ao mesmo tempo, não têm nenhum interesse ou preocupação especial para modificar seu julgamento". 24

Esse aspecto pedagógico doestudo da "cena" histórica tambémfoi notado por Rousseau. Embora não sendo propriamente um historiador, é também um homem do século XVIII, e divide com Voltaire eHume um certo terreno comum: o interessepela natureza humana, pela observação dos costumes dos homens, e a aspiração de imparcialidade. E a história é a cena privilegiada para a observação e o conhecimento dos homens. 0 mundoéum espetáculo que deve ser apresentado ao jovem para que veja os homens sem máscaras, e deles se apiade - "0 sentimento mais inteligente que o homem pode ter de sua espécie" - sem, contudo, querer assemelhar-se a eles. A história fornece essa perspectiva privilegiada de acesso ao passado para melhor conhecer os homens, de modo a "ver a cena" sem poder "atuar nela": "Para conhecer

\footnotetext{
${ }^{23}$ Hume. 1985, Op. cit., p. 566.

${ }^{24}$ Hume. 1957, Op. cit., X, i, § 89.
} 
os homens é preciso vê-los agindo. Na sociedade ouvimo-los falando: mostram seus discursos, escondem suas ações; mas na história estão sem véus e os julgamos pelos fatos". Conhecer melhor os homens, para melhor julgá-los e a eles não se assemelhar. "Queseriaentão necessário parabem observar os homens? Um grande interesseem conhecê-los, uma grande imparcialidade em julgá-los, um coração bastante sensível para conceber todas as paixões humanas sem as sentir" ${ }^{25} 0$ tema da imparcialidade retomado. Por isso, não surpreende que Rousseau escreva a Hume para elogiar a imparcialidade de sua História: "vossas visões, vossa espantosa imparcialidade, vosso gênio, elevar-vos-iam muito acima dos homens se disso não vos impedira vosso bom coração..." " Uma qualidade pela qual o louva também Voltaire:

0 furor dos partidos privou a Inglaterra por muito tempo de uma boa história como de um bom governo. Aquilo que um tory escrevia era negado pelos whigs, desmentidos por sua vez pelos tories. Rapin-Thoyras, estrangeiro, parecia ser 0 único a ter escrito uma história imparcial; vê-se ainda a mancha do preconceito até mesmo nas verdades que Thoyras relata, enquanto que no novo historiador [Hume] descobre-se um espírito superior a seu objeto, que fala das fraquezas, dos erros e das barbáries, como um médico fala das doenças epidêmicas. ${ }^{27}$

Era então conforme ao paradigma de seu tempo que Hume aspirasse à imparcialidade para seu discurso histórico. Contudo, procurava fundar essa aspiração num alicerce mais sólido: a teoria política. A busca de um ponto de equilíbrio para os lados em disputa orientava-se pela própria forma de governo inglês, uma monarquia mista, que combinava elementos republicanos e monárquicos. Essa ligação entre a imparcialidade da narrativa histórica e as formas de governo já havia sido apontada por Montesquieu no Espirito das Leis, porém com consequiências negativas para a história:

Nas monarquias completamente absolutas, os historiadores traem a verdade, porque não têm liberdade para dizê-la. Nos Estados extremamente livres, traem a verdade por causa da própria liberdade, que, sempre produzindo divisões, cada qual se torna tão escravo dos preconceitos de sua facção como o seria de um déspota. ${ }^{28}$

${ }^{25}$ Roussenu, J.J. Emilio, ou da Educação. In: Obras Completas. Porto Alegre: Globo, 1962. p. 267ss. "Só os maus são célebres, os bons são esquecidos ou ridicularizados".

${ }^{26}$ Roussenu, J.J. Carta a David Hume, fevereiro de 1763. Apud Bongie, L. L. David Hume: Prophet of the CounterRevolution. Oxford: Clarendon Press, 1965. p. 10.

${ }^{27}$ Votraire. Réflexions... sur l'histoire d'Angleterre de M. Hume. In: —. Mélanges Historiques, II, 1830, Op. cit., p. 420.

${ }^{28}$ Montesquieu. Do Espírito das Leis. São Paulo: Abril Cultural, 1979. III, xix, 27. p. 280. 
Porém, numa monarquia mista como a inglesa, pensava Hume, o historiador teria condições de manter-se equidistante das pressões partidárias e do governo constituído, para poder interpretar com liberdade e justeza os acontecimentos que mais alimentavam a polêmica nas questões políticas. E com isso marca sua distância daqueles que consideravam a forma mista do governo inglês, "o qual não é inteiramente monárquico, nem inteiramente republicano"29 como uma infeliz contingência a ser corrigida, mas como uma configuração possível do exercício do poder, uma forma legítima de governo a merecer tratamento teórico como qualquer outra. Esta liberdade desfrutada pela narrativa histórica vinculava-se à instituição inglesa mais geral da liberdade de imprensa, elogiada por Hume no ensaio "Da Liberdade de Imprensa": "Nada neste país é mais capaz de surpreender os estrangeiros do que a extrema liberdade que desfrutamos de comunicar ao público quanto nos aprouver, e de censurar abertamente qualquer medida que possa ser tomada pelo rei ou por seus ministros". E esta liberdade tem sua condição de possibilidade na forma do governo inglês: "A razão devido à qual nos concedem tal liberdade parece derivar da forma mista de nosso governo, o qual não é inteiramente monárquico nem inteiramente republicano" ${ }^{30}$ É certo que o caso da imprensa não se compara imediatamente ao da história. A imprensa é invariavelmente associada ao calor do debate e à expressão apaixonada da opinião. Ele ilustra, contudo, a importância da palavra e de sua garantia, em meio ao fervor partidário.

Enganavam-se, portanto, aqueles que julgavam ser impossível produzir uma história imparcial numa sociedade dividida em partidos. Aqueles que assim caracterizavam a sociedade inglesa não compreendiam bem a verdadeira natureza da forma de governo inglês, que não era constituído apenas das facções inerentes a um processo republicano, mas possuía também 0 sentido da unidade nacional e da estabilidade decorrentes de seu aspecto monárquico. Alguém que escrevesse história nessa sociedade, ao contrário de estar necessariamente voltado à parcialidade ao fracasso, na verdade disporia de um ponto de vista privilegiado, desfrutando do clima único que uma monarquia mista poderia oferecer, dando acesso a dois aspectos da organização social, antagônicos, mas complementares, cuja harmonização era necessária ao bom andamento dos negócios do Estado.

Outra intervenção exemplar da teoria política na história éo tratamento humeano da questão da constituição inglesa a partir de suas posições anti-contratualistas. Tal questão constitui talvez o principal roteiro político que organiza a totalidade das páginas da História da Inglaterra, por isso vale a pena resumi-la aqui.

\footnotetext{
${ }^{29}$ Нuмe. 1980, Op. cit., p. 95.

${ }^{30}$ Hume. Id. Ib., p. 263.
} 
Uma noção cara aos ingleses - não apenas aos whigs, mas a todos os patriotas-era a de que as liberdades inglesas eram um evento singular, único no contexto europeu, einteiramente devido ao caráter também único da constituição inglesa. 0 ponto de vista whig acerca da historia inglesa era de que as liberdades eram conquista muito antiga, fruto de um pacto entre súditos e governantes, que se traduzia nas práticas legais em todos os períodos, equeera tomado como sendo a "antiga constituição", sempre retomada apesar dos desvios e traições dos maus governos. A política liberal recorria assim à história para fundar sua prática na autoridade do passado e da tradição. Historiadores como Rapin-Thoyras e Bolingbroke forneciam à causa liberal uma suposta reconstrução da continuidade das liberdades inglesas, que remontariapelo menos ao tempo de uma primeira constituição feudal, mostrando com isso que as liberdades inglesas já existiam e eram usufruídas pelo povo numa época anterior à Magna Carta. 0 essencial dessa visão histórica, conhecida por "constitucionalismo antigo", era a idéia de "uma unidade e continuidade além das vicissitudes da história e das diferenças das formas constitucionais". 31

Tal interpretação visava destacar os avanços do privilégio dos súditos contra a prerrogativa monárquica. Na história, o privilégio era marcado pela participação crescente dos comuns no parlamento. Tratava-se, pois, de afirmar a presença dos comuns no governo nos diversos períodos da história inglesa, desde os primeiros povos. A fraqueza dessa interpretação residia na própria concepção de quem seriam afinal os membros da sociedade pertencentes a esta classe. Se os comuns compreendiam os habitantes das cidades, comerciantes, a pequena nobreza, então não seria mesmo possível identificá-los defendendo a causa da liberdade desde as tribos bárbaras, por exemplo. Trata-se de uma classe definida em primeiro lugar por sua função econômica, e depende dos avanços da economia para tornar-se representativa. A versão whig da história inglesa, além de ignorar a trama das relações econômicas, fazia um uso bastante vago da noção de privilégio.

Hume escreve a História da Inglaterra tendo em conta esse tipo de explicação dos eventos relacionados com a constituição e as liberdades inglesas. Mas seu texto vai além de produzir um mero contraponto às visões whig como a história de Bolingbroke, por exemplo. A história é um desdobramento do projeto humeano de uma ciência do homem, no qual todos os eventos, inclusive aqueles relacionados com o progresso das liberdades inglesas, são explicados sobretudo pelas teorias filosóficas. Assim, a questão da antigüidade da constituição inglesa representa a contrapartida histórica de um tema que figura entre os principais da teoria política de Hume: o do contrato social.

${ }^{31}$ ForBes, D. 1975, Op. cit., p. 244. 
A crítica humeana à teoria whig do contrato social é bem conhecida. Tem sido tema dos estudiosos da filosofia de Hume, que vêem nessa rejeição das teses contratualistas a marca distintiva da teoria política humeana frente às outras, notadamente a de Locke. As teorias contratualistas atribuem a origem do governo a alguma forma de pacto social estabelecido por meio do consentimento racional dos homens, que constitui toda a garantia da legitimidade do poder político. ${ }^{32}$ Hume contesta essas tentativas de fundamentação da origem e legitimidade do governo como pontos de direito, preferindo tratá-la como uma questão de fato.

No ensaio "Do Contrato Original" Hume reconhece explicitamente que os partidos políticos, para poderem garantir a própria subsistência, devem associar à conduta prática um "sistema de princípios filosóficos ou especulativos" que possa "proteger e secundar o esquema de ação" adotado. Assim teriam procedido os partidos tory e whig: o primeiro, "filiando o governo à Divindade, exorta à obediência passiva, defendendo a prerrogativa do soberano contra qualquer tentativa de rebelião ou violação por parte dos súditos"; 0 segundo, supondo "a existência de uma espécie de contrato original" pelo qual os governos dependeriam "inteiramente do consentimento do povo", dá a este o direito da resistência à autoridade, sempre que julgar tal contrato violado. ${ }^{33}$

Quanto ao direito divino, o comentário de Hume é breve e carregado de ironia: "Que a Divindade é o autor último de qualquer governo não o negará ninguém que aceite uma providência geral e admita que todos os acontecimentos do universo são regidos por um plano uniforme, e conduzem a sábios fins". Mas, nesse sentido, até o mais sábio e legítimo dos príncipes não pode alegar que sua autoridade seja mais inviolável que a de um magistrado inferior, um usurpador, ou mesmo um salteador. "Tudo o que efetivamente acontece está contido no plano ou intenção geral da providência", por isso "as causas que em cada Estado fizeram surgir o poder do soberano são as mesmas que nele estabeleceram todas as jurisdições menores e todas as autoridades limitadas" ${ }^{34}$ Assim disseminado, o direito divino cabe a todos igualmente, portanto a ninguém.

Quanto ao consentimento do povo, num certo sentido ele está na origem "de todo poder e jurisdição": na formação dos governos primitivos, os homens, voluntariamente, "renunciaram a sua liberdade natural e acataram leis ditadas por seus iguais e companheiros". Mas a história nos mostra que tal consentimento éprecário. Era concedido,

\footnotetext{
${ }^{32}$ Hoввes. Leviatã. São Paulo: Abril Cultural, 1979. Livro I, cap. XVII. Locke. Segundo Tratado sobre o Governo. São Paulo: Abril Cultural, 1978. caps. VII-IX.

33 Hume. 1980, Op. cit., p. 231.

${ }^{34} I d . I b .$, p. 231.
} 
por exemplo, a um chefe para que comandasse em tempo de guerra: este, contudo, ao retornar a paz, detinha pouco poder, governando "mais pela persuasão que pela força". 35 Demorou algum tempo até que os chefes pudessem de fato subjugar os súditos pela autoridade. Além disso, o consentimento não tinha o caráter formal de um contrato original: não representava um texto escrito e firmado que garantisse as liberdades dos súditos, e ao qual estes pudessem recorrer em caso de tirania do governante. Tratava-se mais de um acordo provisório e imperfeito, vinculado à situação particular de cada comunidade humana. Dificilmente teria o caráter de pacto generalizado de obediência, de resto pouco compreensível entre selvagens. Nos primeiros governos, os homens reconheciam temporariamente as vantagens de submeterem-se a um chefe em tempo de guerra; depois, o hábito os convencia dàs desvantagens da manutenção do governo mesmo em tempo de paz. 0 verdadeiro fundamento dos primeiros governos repousava no interesse mais que no direito, na força mais do que no pacto.

0 papel da violência na formação dos primeiros governos é amplamente confirmado pela história. É também o fator sempre presente na instalação de novos governos. E isso deve ser aceito como uma questão que pode ser estabelecida empiricamente, apesar das objeções teóricas que poderiam opor-se à vinculação da legitimidade do poder a tal fundamento.

Afirmo que jamais as coisas humanas permitirão tal consentimento [popular], e raramente algo que aparente sê-lo; e que a conquista, ou a usurpação, ou mais simplesmente a força, mediante a dissolução dos antigos governos, é a origem de quase todos os novos governos que o mundo viu nascer. E que, nos poucos casos em que possa parecer ter havido um consentimento, este foi geralmente tão irregular, tão limitado ou tão misturado com a fraude e a violência, que não se lhe pode atribuir grande autoridade. ${ }^{36}$

De resto, as teorias contratualistas, que vinculam o dever de obediência política ao consentimento, também podem ser refutadas com argumentos filosóficos. Os deveres morais são de duas espécies: naturais, quando conduzem os homens por uma espécie de "instinto" e "propensão natural" a comportamentos tais como o amor pelas crianças, a gratidão ou a piedade; ou artificiais, quando derivam de "um sentido de obrigação, quando consideramos as necessidades da sociedade humana e impossibilidade de preservála se esses deveres forem descurados". São dessa natureza os deveres de justiça (respeito à

${ }^{35}$ Id. 1 b., p. 232.

${ }^{36}$ Id. Ib., p. 234. 
propriedade), de lealdade (ou cumprimento das promessas) e de fidelidade (ou obediência aos magistrados). Tais deveres contrariam os instintos naturais de amor a si-próprio e expansão ilimitada da posse, e só podem ser produto da experiência e da observação, que nos apontam o interesse da preservação da paz e da ordem pública para a manutenção da sociedade. "A observação desses interesses gerais e evidentes é a fonte de toda sujeição e de toda obrigação moral que a ela atribuímos" ${ }^{37}$ Assim, o dever de fidelidade e obediência ao governo não pode ser derivado daquele de lealdade ou cumprimento das promessas, como querem as teorias contratualistas; ambos os deveres derivam do interesse na manutenção da sociedade, embora o dever de lealdade seja anterior, na medida em que tem origem na sociedade enquanto tal, que Hume considera muito anterior ao governo.

Na História da Inglaterra o tema do contrato não é explicitado. Mas é possível reencontrá-lo implícito no relato da origem e desenvolvimento da forma de governo inglês. Ao longo do texto, a discussão filosófica em torno do tema do contrato social surge no tratamento da questão específica da antigüidade da constituição inglesa. 0 estudo dessa questão permite identificar com clareza a articulação entre teoria política e história, porque, neste caso, são os princípios da teoria filosófica da obediência política (allegiance), encontrados no Tratado e nos Ensaios, que vêm fundar a explicação dos eventos que marcaram a formação histórica do governo inglês. No caso específico da versão whig da história da Inglaterra, a constituição faz o papel do contrato firmado entre governo e povo, como garantia de obediência e liberdade; a defesa whig da antigüidade da constituição, de seu caráter originário na formação da nação inglesa, equivale a propor seu valor de contrato original. Por isso, Hume desenvolve uma ampla argumentação contra as principais teses históricas invocadas em defesa da teoria da antigüidade da constituição inglesa, a partir da qual é possível configurar a dupla articulação, histórica e filosófica, de uma questão da teoria política: o que na filosofia de Hume apresenta-se como argumentação anti-contratualista, na história traduz-se nas posições anticonstitucionalistas.

Podemos ilustrar essa articulação na História da Inglaterra a partir da época moderna. 0 aumento da liberdade pessoal, que decorreu do fim da lei feudal, foi interpretado pelos liberais como resultado da moderação da prerrogativa real por respeito aos princípios da constituição. Hume discorda, atribuindo esse aumento da liberdade justamente à concentração do poder nas mãos do soberano, em detrimento do poder dos nobres. Foi a decadência da aristocracia, e não a moderação da prerrogativa, que inaugurou

${ }^{37}$ Id. Ib., p. 237. 
tempos de maior respeito à constituição. Durante muito tempo, a liberdade pessoal, resgatada à estrutura feudal, conviveu com o crescente absolutismo monárquico. Assim, era "natural" para Jaime I, sucessor de Isabel I, "tomar o governo como o encontrou" e prosseguir com as medidas que tornaram o governo anterior tão popular.

Mas, aí onde Hume vê continuidade, o historiador liberal Bolingbroke constata uma ruptura. Foi por desconhecer as consequiências da mudança do equilíbrio das propriedades para o exercício do poder que Jaime não pode contar com os benefícios de que usufruíra Isabel: 0 amor de seu povo e a sua obediência. ${ }^{38}$ Já a interpretação de Hume reconhece que Jaime falhou apenas por não ter a "penetração" de descobrir que as "circunstâncias" eram outras, e que seu "caráter" não era adequado para sustentar uma autoridade absoluta. ${ }^{39}$ Com efeito, foi no seu reinado que se completou uma mudança na ordem social já iniciada há tempos. 0 surgimento do comércio há muito vinha contribuindo para desbaratar as imensas fortunas dos barões, que tanto ameaçavam o rei e o povo. Ao mesmo tempo, os pequenos proprietários também se arruinavam, o que permitiu a ascensão da gentry - "aquela classe que compunha a camada dos comuns", que aumentava dia a dia sua autoridade. 0 parlamento descobrira sua grande força de pressão: a não concessão dos suprimentos financeiros solicitados pelo rei Jaime I, o qual em breve viu-se dependente dos representantes do povo.

A partir desse governo os súditos ingleses passaram cada vez mais a pensar a constituição inglesa em termos de uma carta de garantia de privilégios e limitação de prerrogativas. Por seu lado, Jaime I e seu sucessor Carlos I persistiram em conduzir as questões de governo segundo a maneira despótica herdada dos Tudors. Um poder que se denominava absoluto, pelo rei e por outras personagens da época, mas que não chegava a significar o poder ilimitado da monarquia anterior: o rei mantinha uma idéia muito diferente da constituição daquela que começava, em geral, a prevalecer entre seus súditos. Carlos I pagou com a vida essa incompreensão. Ele não percebeu que as mudanças sociais "requeriam um novo plano de administração", e quis manter a prerrogativa de que toda determinação emanaria da vontade do rei. Contudo, nem rei, nem povo podiam apoiar suas reivindicações sobre o "teor uniforme das leis inglesas". Em diferentes épocas, muitas "exceções" e "contradições" emanaram da "natureza flutuante da constituição inglesa". Mas em nenhuma época mais do que nessa pareceu "evidente" o quanto eram "confusas

38 BoLINGBROKE, L. Remarks on the History of England. In: Historical Writings. Chicago: The University of Chicago Press, 1972. pp. 277 s.

${ }^{39}$ Hume. 1983, Op. cit., xlviii, nk, p. 562. 
e incertas" as idéias a respeito da constituição. ${ }^{40}$ "Os limites incertos e indefinidos da prerrogativa e do privilégio foram ansiosamente disputados durante todo esse período". ${ }^{41}$

0 caso dos poderes de Isabel é mais um momento na história das alterações por que passou a constituição inglesa, que não deve ser julgado como usurpação das liberdades dos súditos, como procediam aqueles que assim encobriam seu espírito faccioso e sua ambição "sob a aparência de formas veneráveis", do cuidado com a tradição de liberdade tão cara aos ingleses. ${ }^{42}$ Antes dos Tudors, os reis tinham menos autoridade, mas o povo também menos liberdade. 0 poder dos barões limitava o do rei, ao mesmo tempo em que oprimia o povo. Seja qual for o período que se tome como exemplo, sempre haverá um período anterior, mais antigo, em que o poder era exercido de maneira diferente e menos digna de imitação pelo seu barbarismo.

Enfim, toda a argumentação de Hume nesse debate pode ser assim resumida:

Por constituição antiga, quer se dizer aqui aquela que prevaleceu antes do estabelecimento de nosso plano atual de liberdade. Havia uma constituição mais antiga, na qual, embora o povo tivesse talvez menos liberdade que sob os Tudors, contudo o rei tinha também menos autoridade: o poder dos barões era um grande obstáculo a este e exercia grande tirania sobre aquele. Mas ainda havia uma constituição mais antiga, isto é, aquela anterior à assinatura das Cartas, quando nem o povo, nem os barões tinham quaisquer privilégios regulares: e o poder do governo, durante 0 reinado de um príncipe habilidoso, repousava quase completamente no rei. A constituição inglesa, como todas as outras, tem estado num estado de flutuação contínua. ${ }^{43}$

Este é o ponto crucial da argumentação humeana contra as interpretações da história inglesa, partidárias da antiguidade constitucional, que fica claro em sua análise das formas de governo dos diversos períodos: o caráter "flutuante" das liberdades usufruídas pelos súditos, e conseqüentemente da constituição do governo inglês. "A constituição inglesa, como todas as outras, tem estado num estado de flutuação constante". ${ }^{4}$ É verdade que em nenhuma época o monarca gozou de poderes completamente absolutos, mas a "balança do poder oscilou bastante entre as várias classes que compõem a nação, e esta estrutura experimentou a mesma mutabilidade que caracteriza todas as instituições

\footnotetext{
40 Id. Ib., pp.303-5.

${ }^{41} I d . I b ., \mathrm{p} .362$.

${ }^{42}$ Id. Ib., p. 305.

${ }^{43}$ Id. Ib., ap.iii, nl, p. 355.

${ }^{44}$ Id. Ib., ap.iii,n1, p. 452.
} 
humanas". ${ }^{45}$ Assim, para se julgar o caso geral da distribuição do poder entre os vários membros que constituem um estado, a pergunta, diz Hume, nunca pode ser: "0 que é melhor?", que só cabe ao exercício do poder em situações particulares, mas unicamente "0 que está estabelecido?" " 46 única "regra de governo" que pode ser empregada para interpretar a história, que seja "inteligível" e dotada de "autoridade", é a "prática estabelecida da época". Ao historiador cabe aplicar bem essa regra aos dados das fontes, recuperando assim "as máximas de administração que prevalecem e têm o consenso universal na época". 47

Em outras palavras, a interpretação da história pelos princípios gerais da teoria política não pode guiar-se por considerações éticas ou normativas, procurando julgar os eventos da história em nome do que deve ser, do melhor governo, por exemplo, mas deve limitar-se a explicar o exercício do poder nas diversas épocas, tal como pode ser estabelecido a partir do testemunho das fontes. Só esta postura metodológica permite escapar das interpretações partidárias, que procuram justificar o presente a partir do passado, em vez de interrogá-lo para corroborar a explicação mais adequada.

Ao final do reinado de Jaime II, encerrando sua História às vésperas da Revolução Gloriosa de 1688 , Hume resume os quatro reinados em que os partidos mais concentraram seus argumentos e alegações. Mostrara que prerrogativa e privilégio, autoridade e liberdade, a coroa e o povo, mantiveram disputa contínua nesse período, e nele alternaram sua predominância. Sobre tais oscilações, os partidos têm interpretações opostas. Dizem os liberais que governos estáveis, além de raramente livres, desencorajam os poderes ativos dos homens expressos na coragem, invenção e gênio. Contra-argumentam os conservadores que as flutuações nesses governos ameaçaram a segurança do povo, afetaram a política externa e a administração interna. Hume concede que a Revolução Gloriosa inaugura uma nova época na constituição inglesa, depondo um rei e estabelecendo no poder uma nova família, decidindo assim inúmeras questões em favor da liberdade. Este acordo acaba por colocar a natureza da constituição acima de toda controvérsia. "E poderá ser justamente afirmado, sem perigo de exagero, que nós, nesta ilha, temos desde então desfrutado, senão do melhor sistema de governo, ao menos do mais completo sistema de

${ }^{45}$ Id. Ib., xxiii, p. 304.

${ }^{46} I d$. Ib., ap.iii, p. 452.

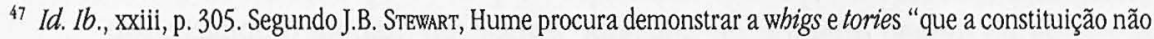
se baseia no direito divino, nem tampouco no contrato original, mas sim na convenção. Eles deveriam perceber que, por ser uma constituição mista, é um tanto vaga, e depende, para seu sucesso, de métodos que não podem ser incluídos na lei da constituiçãa". STEWART, J.B. The Moral and Political Pbilosophy of David Hume. New York: Columbia University Press, 1963. p. 232. 
liberdade que foi conhecido pela humanidade". ${ }^{48}$ Tal afirmação poderia parecer uma concessão gratuita à versão dominante whig dos fatos, se não decorresse das constantes ponderações sobre a balança do poder e a natureza da constituição ao longo de toda Historia da Inglaterra, a maioria das vezes com inferências contrárias à interpretação whig.

Tanto é assim que, em seguida a tal elogio, Hume retoma as críticas já conhecidas. "Nãoéde admirar que estes eventos tenham sido, pela interpretação facciosa, extremamente encobertos e obscurecidos. Ainda não surgiu um homem que tenha considerado inteiramente a verdade, e ousado expô-la, sem cobertura ou disfarce, ao olhar do público preconceituoso". Mesmo o partido da liberdade não tem mostrado suficiente "liberdade de pensamento", tendo "fins" mais nobres do que os "meios" que com frequiência emprega. A outra facção [os tories] desde a revolução busca popularidade empregando por vezes artifícios idênticos. Mas o partido whig, que por setenta anos desde então tem mantido o controle do governo, provou que o que às vezes pode ser benéfico para o estado "provou-se destrutivo para a verdade histórica". ${ }^{49}$ Se Hume nesta questão, como em tudo o mais reivindica a moderação, não será apenas por uma espécie de pragmatismo político que o faria benquisto pelas partes em disputa. Antes, a moderação é o acompanhante natural da atitude filosófica, vale dizer científica, diante do objeto de conhecimento. As inferências da ciência política não servem às facções, não podem incendiar paixões: a razão, sabemos desde o Tratado, é uma paixão calma.

Recebido em abril de 2004.

${ }^{48}$ Hume. 1983, Op. cit.,Lxxi, p. 531.

${ }^{49}$ Id. Ib., lxxi, p. 532 s. 